\title{
The Discovery of Peking Man*
}

$\mathrm{I}^{\mathrm{N}}$ his Croonian lecture on Sinanthropus or Peking man, Prof. Davidson Black gave a full and detailed account of the circumstances leading up to the discovery of the skeletal and cultural relies of this primitive humen type and of the conditions, geological and other, in which they were found.

The first indication of the presence of early man to be found on the site was in 1921 when Dr. J. C. Anderssen, then mining adviser to the Chinese Government, noticed fragments of white quartz among loose talus at the foot of fossiliferous deposits exposed in the south wall of a disused quarry in the Ordovician limestones at Choukoutien. As no quartz of any kind occurs naturally in this part of the Choukoutien area, he at once inferred the presence of primitive man. From this point Prof. Black described the investigations which led to the discovery of a fossil tooth, first announeed in 1926 on a report from Uppsala, where material from Choukoutien was under investigation; the discovery of the fossil tooth by Dr. Böhlin in 1927, upon which was based the recognition of a new human genus, Sinanthropus; and the discovery of the first and second of the two skulls in 1929 and 1930 by Dr. W. C. Pei, under the Cenozoic Research Laboratory, which was organised by the Geological Survey of China in 1929 and now functions as an integral part of that service. In 1930 the Geological Survey acquired by purchase full title to the Sinanthropus site, which is thus preserved to science for all time.

In 1931 Dr. Pei discovered artifacts and evidence of Peking man's use of fire in an undisturbed fire. blackened stratum. Prof. Black also referred to the other skeletal fragments recently described, as well as to six lower jaw fragments, of which an account is to appear shortly. The endocranial cast which has been prepared indicates that Sinanthropus was right-handed and possessed a nervous mechanism for the elaboration of articulate speech.

In his account of the conditions of the discovery

* Substance of the Croonian lecture delivered by Prof. Davidson Black before the Royal Society on December 8 .
Prof. Black was on what was probably to most of his audience less familiar ground. Channels and caverns have been hollowed out of the Ordovician limestone by the solution action of ground water; and after the elevation of the formation, erosion removed the overlying strata. Fissures which formed have been filled and these deposits converted into travertine.

The cavern occupied by Sinanthropus was large, of irregular shape, and opened towards the river valley to the east. Throughout the time it was being gradually filled by detritus, it was wholly or in part occupied by Sinanthropus. His occupation must have extended over hundreds, probably thousands, of years, for more than thirty metres of undisturbed strata remain, showing evidence of his presence throughout. During the later part of his occupation the fauna did not change, but remained typically that of the upper part of the Lower Pleistocene.

Most of the northern limestone wall limiting the original cave has been removed by modern quarrying operations exposing the solidified detritus. Up to 1932, excavations of the actual deposits have been confined to the regions accessible from the northern face. Work is now progressing along the line of contact between the accumulated deposit and the southern wall of the original cave.

The modern cave of Kotzetang is really the result of recent excavation, made probably by quarrymen, in the relatively unconsolidated portion of the great stratified breccia comprising the eastern portion of the main Choukoutien deposit. The northern wall is part of the original northern wall of the cavern.

Prof. Black also referred to the artifacts and the recent study of them by Dr. W. C. Pei and P. Teilhard de Chardin, from which it is concluded that Sinanthropus, "culturally speaking, is to be considered as an early representative of the Old Palæolithic cycle, but his craft displays a crudity which indicates that he but obeyed and never mastered the materials with which he worked"

\section{Capacitance [Hygroscopy and some of its Applications}

By Dr. W. Lawrence Batus, F.R.s.

COME experiments were briefly noted in this journal last April ${ }^{1}$ whereby the high dielectric constant of water was used to indicate variations in the water-content of substances contiguous to a leaky condenser, by means of a resonance method. It would seem that other workers are exploring the same track, with the difference that they draw samples which are placed in special condensercontainers for measurement, whereas I prefer to take full advantage of the method in evading the ubiqui. tous 'sampling-error' so far as possible; even at the sacrifice of some accuracy in the actual determination. Great accuracy is probably unobtainable in any case ; the dielectric constant even of free water is not a constant, but the margin of difference between water around 80 and most other common substances below 8 is large enough for most classes of comparative work.

The necessary apparatus is as portable as an attaché case, and is proving itself to be of versatile utility. Examples will shortly be given. On the analogy of resistance thermornetry, I suggest that the general technique might be termed 'capacitance hygroscopy'.

The arrangement at present used is necessarily capable of improvement in electrical design, but it functions very usefully when its limitations are respected, especially since the discovery of papers by Lattey and his collaborators has allowed voltagetuning to be incorporated." This is done by applying the resonator voltage to the grid of a second valve, the anode current of which then indicates the voltage, as in the Moullin thermionic voltmeter ${ }^{3}$; the coupling between the generator and resonator can be kept very loose, and a feeble and portable generator used with safety. The triple circuit shown in Fig. 1 is also a plan of the arrangement. It undergoes small zero shifts due to temperature and also to earth-capacity, but these are eliminated by zero-setting with one variable condenser, prior to nueasurement on the

No. 3294, VoL. 130] 